\title{
Bioavailability and molecular composition of dissolved organic matter from a diffuse hydrothermal system
}

\author{
Pamela E. Rossel ${ }^{\mathrm{a}, \mathrm{b}, *}$, Aron Stubbins ${ }^{\mathrm{c}}$, Philipp F. Hach ${ }^{\mathrm{d}}$, Thorsten Dittmar ${ }^{\mathrm{b}}$ \\ ${ }^{a}$ HGF-MPG Group for Deep Sea Ecology and Technology, Alfred Wegener Institute Helmholtz Center for Polar and Marine Research, Am Handelshafen 12,27515 Bremerhaven, Germany

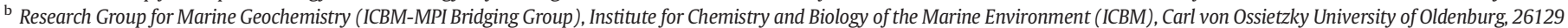 \\ Oldenburg, Germany \\ c Skidaway Institute of Oceanography, Department of Marine Sciences, University of Georgia, Savannah, GA 31411, United States \\ d Max Planck Institute for Microbiology Bremen, Biogeochemistry Group, Celsiusstr. 1R 1337, 28359 Bremen, Germany
}

\section{A R T I C L E I N F O}

\section{Article history:}

Received 23 December 2014

Received in revised form 1 July 2015

Accepted 1 July 2015

Available online 15 July 2015

\section{Keywords:}

Diffusive hydrothermal systems

Dissolved organic matter

Chromophoric dissolved organic matter

Organic matter degradation

Labile

Recalcitrant

Fourier-transform ion cyclotron resonance

mass spectrometry

\begin{abstract}
A B S T R A C T
Fluids from the diffusive hydrothermal vent Woody located at the Menez Gwen hydrothermal field were collected directly from a fissure using a Kiel pumping system (KIPS). The fluids were incubated in a biodegradation experiment with the resident microbial community at in situ temperature $\left(55^{\circ} \mathrm{C}\right)$. In addition to the initial fluid $\left(\mathrm{T}_{0}\right)$, sub-samples were collected at three time points: $12.5 \mathrm{~h}\left(\mathrm{~T}_{1}\right), 38 \mathrm{~h}\left(\mathrm{~T}_{2}\right)$ and $180 \mathrm{~h}\left(\mathrm{~T}_{\text {final }}\right)$. Whole water samples were characterized by spectrophotometry and for dissolved organic carbon (DOC) and total dissolved nitrogen (TDN) concentrations. Solid-phase extracted dissolved organic matter (SPE-DOM) was molecularly characterized using a 15 Tesla Fourier-transform ion cyclotron resonance mass spectrometer (FT-ICR-MS). Based on $\mathrm{Mg}^{2+}$ concentrations, vent fluids were diluted ca. 1:99\% with seawater. SPE-DOC concentrations remained constantly low ( $30 \mu \mathrm{M})$ over the course of incubation, while DOC and TDN (1180 $\mu \mathrm{M}$ and $16 \mu \mathrm{M}$, respectively, at $\mathrm{T}_{0}$ ) decreased sharply (to $80 \mu \mathrm{M}$ and $9 \mu \mathrm{M}$, respectively, at $\mathrm{T}_{\text {final }}$ ). This biolabile DOC is likely composed of volatiles and short-chain hydrocarbons, and the reason behind their extraordinarily high concentration remains unknown. Molecular characterization of SPE-DOM in fluids and seawater identified over 3000 molecular formulae, which were separated into different groups according to their reactivity. The half-life of the more reactive groups ranged between $6-7 \mathrm{~h}, 18-21 \mathrm{~h}$ and $5-106$ days, and represented 7.3, 2.0 and $7.5 \%$ of the total formulae present in $\mathrm{T}_{0}$, while the majority (83\%) did not exhibit any significant trend during the experiment. Despite the small molecular changes in SPE-DOM, a decrease in the number of formulae and average molecular mass was observed, the latter consistent with an increase in the spectral slope over the wavelength range 275-295 $\mathrm{nm}\left(\mathrm{S}_{275-295}\right)$ during the experiment. An increase in aromatic molecular formulae during the incubation was also corroborated by a concurrent increase in the absorption coefficient at $254 \mathrm{~nm}$ normalized to DOC concentrations ( SUVA $_{254}$ ), an optical indicator of aromatic content. Thus both FT-ICR-MS and optical properties over the course of the incubation corroborated a decrease in molecular mass and increase in aromaticity. This study is the first to report the optical and molecular transformations of bio-labile DOM from diffusive hydrothermal systems.
\end{abstract}

(c) 2015 Elsevier B.V. All rights reserved.

\section{Introduction}

Hydrothermal activity has been reported for a wide variety of locations, among which black smokers, expelling high temperature fluids to the overlying seawater, have received greatest attention (German and Seyfried, 2014). However, high temperature fluids may represent

\footnotetext{
* Corresponding author at: HGF-MPG Group for Deep Sea Ecology and Technology Alfred Wegener Institute Helmholtz Center for Polar and Marine Research, Am Handelshafen 12, 27515 Bremerhaven, Germany.

E-mail addresses: prossel@mpi-bremen.de (P.E. Rossel), aron.stubbins@skio.uga.edu (A. Stubbins), phach@mpi-bremen.de (P.F. Hach), thorsten.dittmar@uni-oldenburg.d (T. Dittmar).
}

only a small fraction of the heat and geochemical fluxes to the ocean compared to those associated with diffusive hydrothermal fluids (Schultz et al., 1992; Elderfield and Schultz, 1996; Wankel et al., 2011). Furthermore, the lower temperatures and longer residence time of diffusive fluids create environments rich in dissolved volatiles, metals, and minerals, making these systems hot spots for microbial communities and biogeochemical cycling (Proskurowski et al., 2008; Wankel et al., 2011). The geochemical energy and temperature provided by these environments create favorable conditions for microbial life, making these systems an analogous habitat to that envisioned for the seafloor biosphere (Summit and Baross, 2001). It has been shown that dissolved organic carbon (DOC) can be depleted in high temperature fluids compared to those with low temperature, and that low molecular 
weight organic compounds may represent an important fraction of DOC in low temperature fluids (Lang et al., 2006; McDermott et al., 2015; Hawkes et al., 2015). In diffusive hydrothermal systems the influence of diverse microbial processes likely impacts the chemical composition of the fluids (Proskurowski et al., 2008; Walker et al., 2008; McCarthy et al., 2011). Methane concentrations are high in all end member hydrothermal fluids, while magnesium $\left(\mathrm{Mg}^{2+}\right)$ is below detection limit in pure hydrothermal fluids and $54 \mathrm{mM}$ in seawater (Bischoff and Dickson, 1975; Lilley et al., 1993), thus methane and $\mathrm{Mg}^{2+}$ concentrations are used to constrain hydrothermal fluid contributions to water samples. Diffusive fluids have been previously defined as fluids released from fissures and a dilution mixture of high temperature fluids and crustal seawater (Von Damm and Lilley, 2004). Accordingly these fluids usually contain 90-95\% seawater by volume (Proskurowski et al., 2008). Consequently, it is expected that the DOM molecular composition will be close to that of seawater. Because deep-sea DOM is considered mainly refractory in nature (Dittmar and Stubbins, 2014 and references therein) and diffusive hydrothermal systems are considered oases for microbial life, it is possible that the DOM from these systems has a labile fraction which may represent an important carbon source for microbial communities in the deep ocean.

There is much to learn about deep ocean DOM. Less than $6 \%$ of the DOM in deep oceanic waters is identified on the molecular level either as monomers $(<1 \%$ identified as amino acids, sugars and organic acids) or as molecular building blocks ( $\sim 5 \%$ represented by benzene polycarboxylic acids, neutral sugars, amino acids, amino sugars and lignin-derived phenols) (Hedges et al., 2000; Dittmar and Stubbins, 2014). The challenge of analyzing DOM is attributable to its high complexity as well as to the fact that it is highly polar and diluted in a seawater matrix (Dittmar and Stubbins, 2014). Solid-phase extraction (SPE) via styrene divinyl benzene PPL columns, which extracts polar to apolar compounds but does not retain small ionic molecules (Dittmar et al., 2008), has been used to efficiently extract DOM from a wide variety of environments. SPE in combination with ultrahigh-resolution mass spectrometry, via the Fourier-transform ion cyclotron resonance technique (FT-ICR-MS), has been applied to resolve on a molecular level complex DOM mixtures from marine (Koch et al., 2005; Osterholz et al., 2014), freshwater (Kujawinski, 2002; Kim et al., 2003; Roth et al., 2013; Ward et al., 2013) and sediment pore water systems (Schmidt et al., 2009; Seidel et al., 2014).

In the current study, samples from the diffusive hydrothermal vent Woody, located at the Menez Gwen hydrothermal field, were collected and submitted to bio-degradation experiments and DOM characterization (bulk DOC, colored dissolved organic matter (CDOM) absorbance, and 15 T FT-ICR-MS) to assess the bioavailability of diffusive vent fluid DOM and how the character of this DOM is altered by biodegradation.

\section{Material and methods}

\subsection{Diffusive hydrothermal fluids and experimental setup}

Hydrothermal fluids were collected directly from a fissure of the Woody diffusive vent system during the cruise M82/3 at the Menez Gwen hydrothermal field on the Mid-Atlantic Ridge $2010\left(37^{\circ} .5^{\prime} \mathrm{N}\right.$, $31^{\circ} 31^{\prime} \mathrm{W}$, Fig. 1a and b). This fissure represents a boundary between sandy, slab-like material and an abundant mussel area (Marcon et al., 2013, Fig. 1a). Menez Gwen is a shallow hydrothermal field $(850 \mathrm{~m}$ water depth) located in a volcanic segment. It is characterized by white chimneys and fluids with high methane and $\mathrm{CO}_{2}$ concentrations, which have been considered to be indicative of hydrothermal circulation through an ultramafic basement (Charlou et al., 2000). At the Menez Gwen unsedimented hydrothermal system, high-temperature end member methane concentrations of up to $3.6 \mathrm{mM}$ have been found, possibly originating from volatile-rich fluid inclusions in the oceanic crust (Reeves et al., 2011). Average Menez Gwen fluid temperatures are around $285{ }^{\circ} \mathrm{C}$, conditions under which fauna is scarce (Charlou et al., 2000). However, at the diffusive Woody vent (Table 1), fluid temperatures are between 67 and $74{ }^{\circ} \mathrm{C}$, and hydrothermal fauna

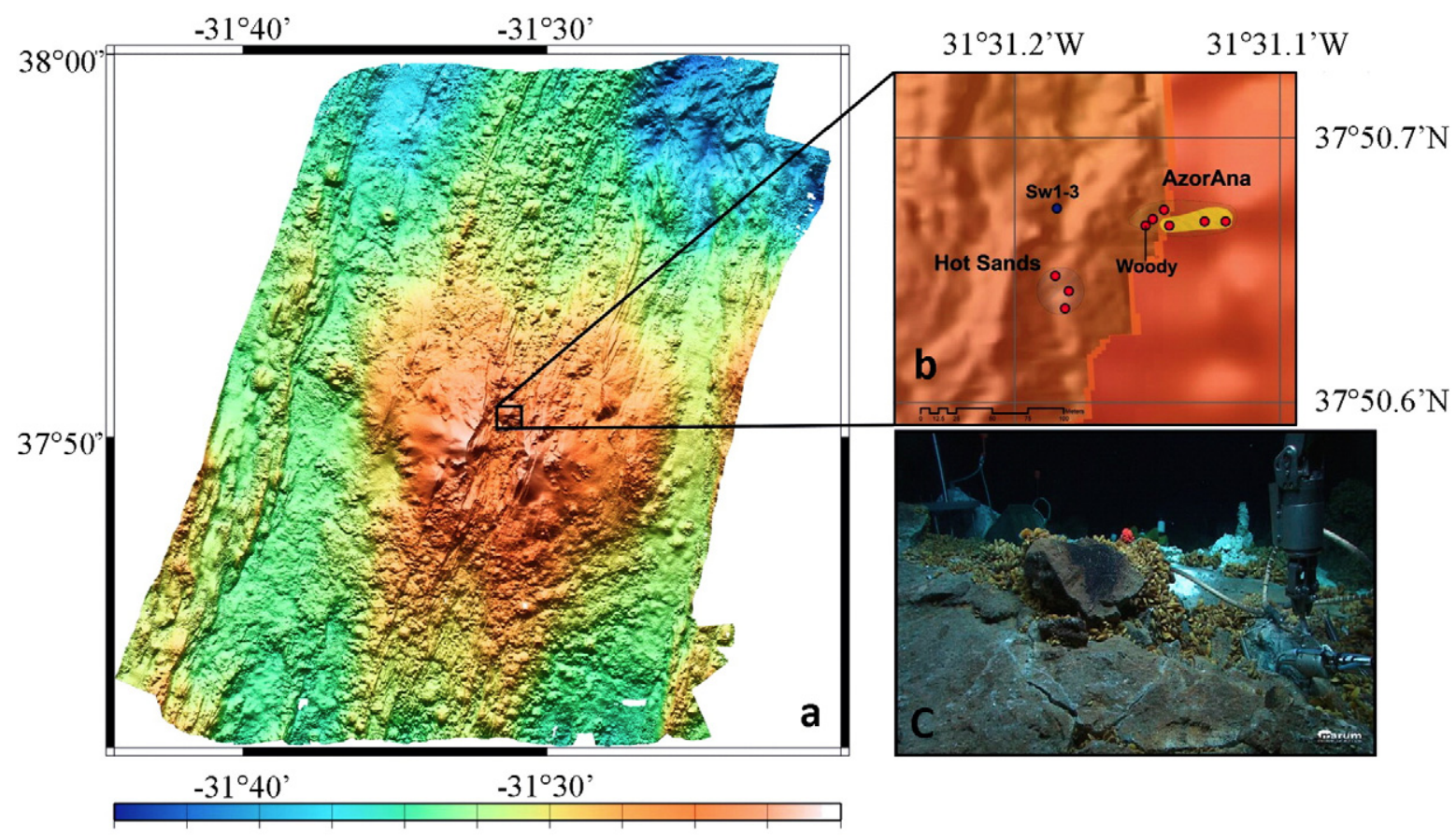

$-2600-2400-2200-2000-1800-1600-1400-1200-1000-800 \quad-600$

Depth (m)

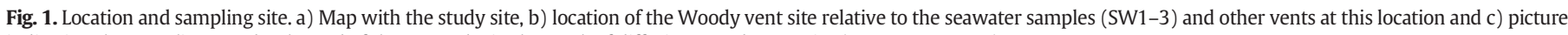
indicating the sampling spot by the end of the KIPS tube in the crack of diffusive Woody vent site (729ROV-6 to -14).

The picture is courtesy of MARUM center for marine environmental sciences, University of Bremen. 
Table 1

General information of seawater and DOM from diffusive fluids during the experiment.

\begin{tabular}{|c|c|c|c|c|c|c|c|c|c|c|}
\hline $\begin{array}{l}\text { Sample name } \\
\text { (M82/3 cruise ID) }\end{array}$ & $\begin{array}{l}\text { Sample type } \\
(\mathrm{Mg} \text { in } \mathrm{mM})\end{array}$ & $\begin{array}{l}\mathrm{CH}_{4} \\
(\mathrm{nM})\end{array}$ & $\begin{array}{l}\text { Time } \\
(\mathrm{h})\end{array}$ & $\begin{array}{l}\mathrm{DOC}^{\mathrm{a}} \\
(\mu \mathrm{M})\end{array}$ & $\begin{array}{l}\mathrm{TDN}^{\mathrm{a}} \\
(\mu \mathrm{M})\end{array}$ & $\begin{array}{l}\text { SPE-DOC } \\
(\mu \mathrm{M})\end{array}$ & $\begin{array}{l}\text { SPE extraction } \\
\text { efficiency (\%) }\end{array}$ & $\begin{array}{l}a_{254} \\
\left(\mathrm{~m}^{-1}\right)\end{array}$ & $\begin{array}{l}\mathrm{SUVA}_{254} \\
\left(\mathrm{~L} \mathrm{mg} \mathrm{C}^{-1} \mathrm{~m}^{-1}\right)\end{array}$ & $\begin{array}{l}\mathrm{S}_{275-295} \\
\left(\mathrm{~nm}^{-1}\right)\end{array}$ \\
\hline SW1 (693-CTD-4) ${ }^{\mathrm{b}}$ & Seawater & 152 & - & 57 & 19 & 29 & 52 & 0.70 & 0.44 & 0.040 \\
\hline SW2 (693-CTD-7) & Seawater & 25 & - & 491 & 19 & 32 & 7 & 1.27 & 0.09 & 0.020 \\
\hline SW3 (693-CTD 13) & Seawater & 7 & - & 86 & 16 & 27 & 31 & 0.70 & 0.29 & 0.057 \\
\hline $\mathrm{T}_{0}{ }^{\mathrm{c}}$ (dive 729 ) & Vent fluid (53.5) & - & - & 1180 & 16 & 29 & 2 & 3.39 & 0.10 & 0.036 \\
\hline $\mathrm{T}_{1}$ & Incubation & - & 12.5 & 377 & 7 & 31 & 8 & 3.59 & 0.34 & 0.039 \\
\hline $\mathrm{T}_{2}$ & Incubation & - & 38 & 174 & 5 & 27 & 16 & - & - & - \\
\hline $\mathrm{T}_{\text {final }}$ & Incubation & - & 180 & 80 & 9 & 30 & 38 & 1.69 & 0.77 & 0.042 \\
\hline
\end{tabular}

a DOC and TDN concentrations were measured with an analytical precision of 6 and $9 \%$, respectively.

b CTD 693-4, -7 and -13 were collected at 800,770 and $600 \mathrm{~m}$ water depth. Methane concentrations in CTD samples indicate some hydrothermal contribution in the samples as background seawater has usually methane concentrations $<5 \mathrm{nM}$.

${ }^{c} \mathrm{Mg}$ concentrations were obtained from diffusive fluids collected during the same cruise (M82/3) and at the same location but during a different dive (719).

abound (Marcon et al., 2013) (Fig. 1c). Consequently, fluids from this location are especially suitable to evaluate the bioavailability of DOM in biogeochemically active diffusive hydrothermal systems.

The fluids collected for the current study were characterized by temperatures of $50-60{ }^{\circ} \mathrm{C}$ measured in situ with a temperature probe mounted parallel to the nozzle inlet (Grbe-schönberg et al., 2006). Based on fluids collected at the same location on a different dive, these fluids have $\mathrm{pH}$ values of 5.5 and $\mathrm{Mg}^{2+}$ concentrations of $53.5 \mathrm{mM}$ (Table 1). $\mathrm{Mg}^{2+}$ concentration in the diffusive vent fluid indicates a mixture of $1 \%$ hydrothermal fluid with $99 \%$ background seawater assuming absence of $\mathrm{Mg}^{2+}$ in end-member hydrothermal fluids (Bischoff and Dickson, 1975; Mottl and Holland, 1978) and $\mathrm{Mg}^{2+}$ concentrations of $53.9 \mathrm{mM}$ for a background seawater sample collected at the Woody site (Koschinsky Personal communication).

Water samples were collected with the Kiel pumping system (KIPS) controlled by the arm of the remotely operated vehicle (ROV) QUEST from the Center for Marine Environmental Sciences, Bremen (MARUM) (Fig. 1c). The materials of the KIPS system that were in contact with the samples are inert and included perfluoralkoxy (PFA), polyetheretherketone, polytetrafluorethylene and high-purity titanium. A PFA tube transports the samples, collected with a titanium nozzle, into the PFA flasks $(675 \mathrm{~mL})$, where they are stored until ROV recovery. Pumping water through the system allows the exchange of at least 4 times the sample volume before filling the flasks with the hydrothermal fluid sample (e.g., Schmidt et al., 2007; Haase et al., 2007). A total of 4 PFA flasks with a combined volume of $1.5 \mathrm{~L}$ from the Woody vent were sub-sampled after ROV recovery and stored in a polycarbonate Nalgene bottle, previously cleaned with ultrapure water at $\mathrm{pH} 2$ and rinsed several times with ultrapure water.

The initial Woody vent fluid sample $\left(\mathrm{T}_{0}\right)$ was incubated in the dark under oxic conditions, without filtration at in situ temperature $\left(55^{\circ} \mathrm{C}\right)$. Sub-samples were collected after $12.5 \mathrm{~h}\left(\mathrm{~T}_{1}\right), 38 \mathrm{~h}\left(\mathrm{~T}_{2}\right)$ and $180 \mathrm{~h}\left(\mathrm{~T}_{\text {final }}\right)$ and stored frozen at $-20^{\circ} \mathrm{C}$ in cleaned polycarbonate Nalgene bottles prior to molecular analysis. In order to compare DOM molecular variations during the experiment and the DOM present in nearby seawater with modest contributions from vent fluids, three samples were also collected using a Niskin bottle rosette during a conductivity-temperature-depth (CTD) cast at the Menez Gwen field. Although $\mathrm{Mg}^{2+}$ concentrations indicative of background seawater were measured in the vicinity $(1.1 \mathrm{~km})$ of our CTD samples, our CTD samples had elevated methane concentrations that decreased from SW1 $>$ SW2 $>$ SW3. Thus, these samples represented a gradient with diminishing contribution of vent fluids in the water column with SW3 as the local seawater that may better represent background molecular characteristics (Table 1, Fig. 1b). All samples were filtered through a pre-combusted $0.7 \mu \mathrm{m} \mathrm{GF/F} \mathrm{filter} \mathrm{(Whatman)} \mathrm{prior} \mathrm{to} \mathrm{further} \mathrm{analysis.}$

\subsection{DOC and TDN concentrations}

Samples were acidified to $\mathrm{pH} 2$ and then DOC and TDN concentrations were determined via catalytic oxidation at high temperature on a TOC-V Shimadzu instrument (Stubbins and Dittmar, 2012). Acidified samples were also extracted using PPL columns (Varian) previously rinsed with methanol according to Dittmar et al. (2008). Ultrapure water at $\mathrm{pH} 2$ was used to rinse salt off the PPL columns. Afterwards, the columns were dried with ultrapure $\mathrm{N}_{2}$ and solid phase extracted (SPE)-DOM was eluted with methanol and stored at $-20{ }^{\circ} \mathrm{C}$ prior to molecular analysis. For the determination of SPE-DOC concentrations, the methanol extracts were evaporated overnight and redissolved in ultrapure water at $\mathrm{pH} 2$ before analysis on the TOC-V Shimadzu. The accuracy and precision of the analysis were confirmed by analyzing aliquots of deep seawater from the Consensus Reference Material Project (CRM; http://yyy.rsmas.miami.edu/ groups/biogeochem/Table1.htm).

\subsection{Optical analysis of DOM}

Ultraviolet-visible absorbance spectra (250 to $800 \mathrm{~nm}$ ) of the chromophoric (colored) fraction of DOM (CDOM) were determined for non-acidified samples using a quartz cuvette placed in the light path of an Agilent $8453 \mathrm{UV}$-vis spectrophotometer. Blank correction was provided by analyzing ultrapure water immediately before the samples. In order to correct for potential instrument drift, the average absorbance between 700 and $800 \mathrm{~nm}$ was subtracted from the blank-corrected absorbance spectra (Stubbins et al., 2011). Dimensionless absorbance (or optical density, OD) data were converted to the Napierian absorption coefficient, $a\left(\mathrm{~m}^{-1}\right)$ (Hu et al., 2002). The Specific UV Absorbance $\left(\mathrm{SUVA}_{254}\right)$ was calculated as the decadic absorption coefficient at $254 \mathrm{~nm}\left(\mathrm{~m}^{-1}\right)$ divided by the DOC concentration ( $\mathrm{mg} \mathrm{L}^{-1}$ ) (Weishaar et al., 2003). SUVA 254 provides an indication of the percentage of DOM that is in the form of aromatic carbon (Stubbins et al., 2008). CDOM spectral quality was also characterized by calculating the spectral slope over the wavelength range $275-295 \mathrm{~nm}\left(\mathrm{~S}_{275-295}\right.$; Helms et al., 2008).

\subsection{Volatile organic compounds}

To evaluate the presence of volatiles, DOM samples were analyzed by high performance liquid chromatography (HPLC; Sykam, Fürstenfeldbruck, Germany) using $5 \mathrm{mM} \mathrm{H}_{2} \mathrm{SO}_{4}$ as eluent. The analysis was performed with an Aminex HPX-87H column (Biorad, München, Germany) at $60{ }^{\circ} \mathrm{C}$ using infrared (smart line 2300, Knauer, Berlin, Germany) and ultraviolet-visible light (UVIS 204, linear instruments Reno) detectors (Graue et al., 2012). Standards included glucose, lactate, acetate, propionate, butyrate, propanol, formate, succinate, methanol, ethanol, oxalate and malate, and the detection limit was $25 \mu \mathrm{M}$ for acetate and $100 \mu \mathrm{M}$ for other volatiles.

\subsection{FT-ICR-MS analysis}

SPE-DOM aliquots were diluted to a final DOC concentration of 10-15 mg C $\mathrm{L}^{-1}$ in a $1: 1$ mixture of methanol:ultrapure water and 
analyzed by direct infusion into the ultra-high resolution $15 \mathrm{~T}$ FT-ICRMS (Bruker Solarix). Analyses were performed with an electrospray ionization (ESI) source in negative ion mode, infusing the samples at $120 \mu \mathrm{L} \mathrm{h}^{-1}$. For each sample, 500 individual broadband scans were obtained and the ion accumulation and capillary voltage were set to $0.35 \mathrm{~s}$ and $4000 \mathrm{~V}$, respectively. To prevent cluster formation, the skimmer 2 voltage of the second ion funnel was set to $50 \mathrm{~V}$. Sample calibration was performed externally and internally using a list of known molecular formula present in an arginine cluster and $>50$ known molecular formulae over the whole mass range of the samples, respectively (e.g., Seidel et al., 2014). Molecular formula assignments were performed with an in-house Matlab (2010) routine that searches for all potential combinations of $\mathrm{C}, \mathrm{H}, \mathrm{O}, \mathrm{N}, \mathrm{S}$, and $\mathrm{P}$ elements with an error $<0.5 \mathrm{ppm}$. For further data analysis, $\mathrm{m} / \mathrm{z}$ peaks with signal to noise ratio $(\mathrm{S} / \mathrm{N})$ below 4 were removed. Formula assignments were performed based on the following criteria: $\mathrm{C} \geq 0$; $\mathrm{O}>(2 \mathrm{P}+\mathrm{S})$; $\mathrm{H} \leq 2 \mathrm{C}+2 ; \mathrm{N} \leq 4 ; \mathrm{S} \leq 2$ and $\mathrm{P} \leq 1$. To remove double assignments i.e., more than one formula for each mass peak, $\mathrm{CH}_{2}$-homologous series were considered and only those ones extended to lower mass range were allowed. Additionally, the combinations of elements NSP, $\mathrm{N}_{2} \mathrm{~S}$, $\mathrm{N}_{3} \mathrm{~S}, \mathrm{~N}_{4} \mathrm{~S}, \mathrm{~N}_{2} \mathrm{P}, \mathrm{N}_{3} \mathrm{P}, \mathrm{N}_{4} \mathrm{P}, \mathrm{NS}_{2}, \mathrm{~N}_{2} \mathrm{~S}_{2}, \mathrm{~N}_{3} \mathrm{~S}_{2}, \mathrm{~N}_{4} \mathrm{~S}_{2}$, and $\mathrm{S}_{2} \mathrm{P}$ were not permitted. After this procedure, it was possible to assign a molecular formula to $69-71 \%$ of all detected $m / z$ peaks in each sample, not considering ${ }^{13} \mathrm{C}$ isotopologues which account for ca. $15-22 \%$ of the detected masses, obtaining a total of 4037 formulae for the whole dataset. In addition to the $\mathrm{S} / \mathrm{N}$ criterion, peaks were removed using a new standardized detection limit (std. DL) defined by the ratio of the 500 most intense ions and the smallest dynamic range in the dataset. The smallest dynamic range was calculated by the ratio between the average of the 500 most intense and the 10 less intense peaks in each sample. If the original intensity was lower than the std. DL, the value was replaced by zero, otherwise the original intensity was retained. This information was later used to normalize the peak intensities in each sample. This procedure is complementary to the one proposed by Riedel and Dittmar (2014) because aside of removing noise (false positives) from the dataset it facilitates maximum comparability among samples by adjusting the detection limit of all samples to the highest (worst) detection limit across all samples.

Molecular information was organized according to the contribution of $\mathrm{CHO}, \mathrm{CHON}, \mathrm{CHOS}, \mathrm{CHOP}$ and CHONS molecular formulae in each sample as well as by the intensity weighted average $H / C_{w a}, O / C_{w a}$, double bond equivalents $\left(\mathrm{DBE}_{\mathrm{wa}}\right)$, and aromaticity index ( $\left.\operatorname{Imod}_{\mathrm{wa}}\right)$ (McLafferty and Turecek, 1993; Koch and Dittmar, 2006). Intensity weighted average molecular formulae were also calculated using the intensity of the formulae for each sample. Additionally, molecular formulae were categorized into different molecular groups. Due to the number of potential isomers, our assignment does not necessarily indicate the presence of a specific molecular structure, but indicates that a specific molecular formula has the same formula as a known molecular group (e.g., Seidel et al., 2014). Molecular groups considered were (Table 2): 1 ) peptide molecular formulae $(2>\mathrm{H} / \mathrm{C}>1.5, \mathrm{O} / \mathrm{C}<0.9$ and $\mathrm{N}>0)$; 2) formulae of unsaturated aliphatics $(2>\mathrm{H} / \mathrm{C}>1.5, \mathrm{O} / \mathrm{C}<0.9$, $\mathrm{N}=0) ; 3)$ saturated fatty acids $(\mathrm{H} / \mathrm{C}>2, \mathrm{O} / \mathrm{C}<0.9)$, without (sat. fatty acids) or with heteroatoms (sat. fatty acids-CHOx); 4) formulae of sugars $(\mathrm{O} / \mathrm{C}>0.9)$, without heteroatoms (sugars) and with heteroatoms (sugars-CHOx); 5) highly unsaturated compounds (AImod $<0.5$ and $\mathrm{H} / \mathrm{C}<1.5) ; 6$ ) polyphenols $(0.67 \geq$ AImod $>0.5$ ) and 7 ) condensed aromatics such as dissolved black carbon (DBC, AImod $\geq$ 0.67 ), divided into 3 subgroups with either $<15$ (DBC $-<15 C), \geq 15$ $(\mathrm{DBC}-\geq 15 \mathrm{C}) \mathrm{C}$ atoms both without heteroatoms (N, S or P) and with heteroatoms (DBC-CHOx). Furthermore, unsaturated aliphatics, highly unsaturated and polyphenol formulae were separated into oxygenrich compounds ( $\mathrm{O}$-rich, $\mathrm{O} / \mathrm{C}$ ratio was $>0.5$ ) or oxygen-poor ( $\mathrm{O}$-poor, $\mathrm{O} / \mathrm{C}$ ratios $<0.5$ ). In the case of $\mathrm{DBC}-\mathrm{CHOx}$ and saturated fatty acidsCHOx, the most intense $m / z$ peaks of the homologous series in which these peaks were present were confirmed based upon the relative

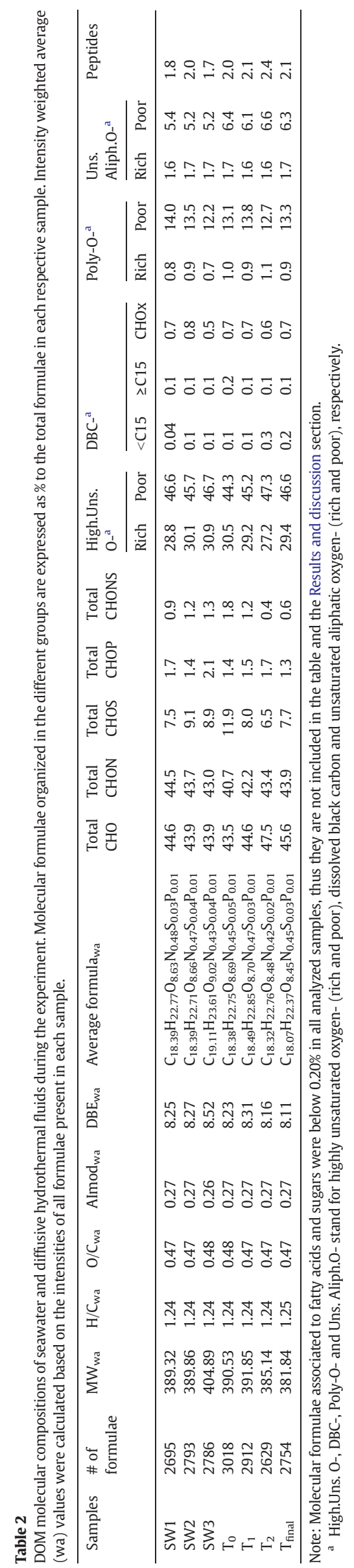


intensities of formulas containing only ${ }^{12} \mathrm{C}$ carbon and the respective ${ }^{13} \mathrm{C}$ isotopologue.

To discuss the DOM molecular variations during the experiment, the following groups of molecular formulae were considered:

1) Degraded, group A: formulae that disappeared or were below the detection limit after $\mathrm{T}_{0}$ (i.e. zero at $\mathrm{T}_{1}, \mathrm{~T}_{2}$ and $\mathrm{T}_{\text {final) }}$. Group $\mathrm{B}$ : compounds that were progressively degraded over time (i.e. their peak intensity fell consistently) and whose intensities reached zero intensity at $\mathrm{T}_{2}$. Group $\mathrm{C}$ : compounds that were progressively degraded over time and whose intensities reached zero intensity at $T_{\text {final }}$. Group D: compounds that were progressively degraded over time and whose intensities did not reach zero.

2) Recalcitrant, group E: molecular formulae that were present in $T_{0}$ and that persisted during the experiment without a consistent trend of production or loss.

3) Produced, formulae that progressively increased relative to $T_{0}$.

Intensity weighted average molecular formulae for these considered groups were calculated based on the intensity of the formulae at $\mathrm{T}_{0}$ to better compare the composition of these different groups. Biodegradation half-life for the molecular formulae that disappeared were calculated in two different ways: 1) using the std. DL as the final relative abundance, and 2) considering a relative abundance equal to zero at the time point where the formula disappeared and did not appear again. Both values are provided as a range of reactivity for the different formulae degraded. In the case of group A, half-life was calculated with the intensity at $T_{0}$ and $T_{1}$, while for the rest of the degraded groups (B to D) the half-life was obtained from the decay in intensity between the respective time points e.g., half-life of group B was calculated from an intensity curve of $T_{0}, T_{1}$ and $T_{2}$. Because each of these degraded groups is defined by the time in which the lowest intensity was detected, a formula included in a group degraded at a later time point is not included in a group degraded earlier.

If labile organic molecules present in diffusive hydrothermal fluids are decomposed during the experiment it is possible that SPE-DOM from diffusive hydrothermal systems may become more similar to the surrounding seawater on a molecular level at the end of the experiment. To evaluate if SPE-DOM from the diffusive hydrothermal system became more similar to SPE-DOM from seawater with the lowest hydrothermal contribution during bio-incubation, the molecular composition of SPE-DOM at each time point of the experiment was compared with SW3 sample. This was done using the relative intensities of the formulae in each sample after normalization described early in the methods and based on a Bray Curtis dissimilarity test performed with the software "R" (e.g., Osterholz et al., 2015). SPE-DOM from North Equatorial Pacific Intermediate Water (NEqPIW) collected at the National Energy Laboratory of Hawaii Authority (Green et al., 2014) was also analyzed on the FT-ICR-MS several times during the day of analysis to evaluate instrument reproducibility and margin of error in signal intensity.

\section{Results and discussion}

\subsection{Comparison of fluid and seawater DOC concentrations}

While DOC concentrations in the vent fluids were two orders of magnitude higher than in seawater (Table 1) and in deep sea waters in general (Dittmar and Stubbins, 2014), vent fluid TDN concentrations were similar to those in seawater (Table 1), suggesting a C-rich, N-poor source of DOM to vent waters. The absorption coefficient of vent fluid DOM revealed higher CDOM levels than in seawater, but similar carbon-normalized aromatic content based upon SUVA values (Table 1). Contrary to bulk DOC, SPE-DOC concentrations were similar in all samples at around $30 \mu \mathrm{M}$ (Table 1).

The DOC concentration in Woody vent fluid was $1180 \mu \mathrm{M}$, which is the highest value ever reported for a diffusive vent system
(Lang et al., 2010; McCarthy et al., 2011; Yamanaka et al., 2013). However, Hawkes et al. (2015) observed highly variable DOC concentrations in hydrothermal fluids, with higher values mainly associated with sedimented hydrothermal systems. McDermott et al. (2015) demonstrated that there are pathways for abiotic synthesis of low molecular mass organics at $\mathrm{H}_{2}$-rich submarine hydrothermal fields. These compounds form during mixing of hydrothermal fluids with seawater, and formate alone can reach concentrations of up to $700 \mu \mathrm{M}$ (McDermott et al., 2015). However, McCollom and Seewald (2007) indicated that hydrothermal alteration of basaltic rocks, like Menez Gwen, generally produces less $\mathrm{H}_{2}$ than alteration of ultramafic rocks, which is consistent with the reported $\mathrm{H}_{2}$ concentrations for Menez Gwen (38 $\mu \mathrm{M}$, Charlou et al., 2000). This $\mathrm{H}_{2}$ concentration is in the lower range $(0.01 \mathrm{mM}$ for Shrimp Hole vent) of those reported by McDermott et al. (2015) and thus it does not appear to be a feasible explanation for the high DOC concentration at the Woody crack. Consistent with this observation, some systems are characterized by high concentrations of formate and acetate (Lang et al., 2010) while others are not (Winkel et al., 2014). Other mechanisms that may add DOC to fluids include thermal decomposition of microbial biomass during mixing in the subsurface, given that temperatures deeper in the Woody crack were $>100{ }^{\circ} \mathrm{C}$ and the presence of biofilms was detected within the fissure (Brault et al., 1988; McCollom, 2008; Reeves et al., 2014). However, based on recently reported concentrations of nitrate $(5-8 \mu \mathrm{M})$ and ammonia $(17 \mu \mathrm{M})$ it seems that most of the TDN in these fluids is inorganic (Winkel et al., 2014) and thus not support the idea of an extra supply of DOC from microbial biomass, which would yield lower DOC:DON ratios. Overall, the reason behind the very high DOC concentration in our diffusive system is unclear. Despite the use of standard, trace-clean procedures during sampling and sample handling (see details in Section 2.1) it is not possible to fully rule out potential contamination of the fluids. Sources of contamination may also include intrusion of particles from the Woody area (see description of the site, Section 2.1).

Acetate and formate concentrations were below the detection limits ( $25 \mu \mathrm{M}$ for acetate; $100 \mu \mathrm{M}$ for formate) in our samples. Additional tests revealed that acetate, formate, aspartate, glutamate and methanol are not retained on the PPL resin after acidification at $\mathrm{pH} \mathrm{2}$, and also not removed via purging in the DOC analyzer (Hawkes, personal communication), thus it is possible that the non-extractable DOC detected in the Woody vent fluids includes low molecular weight volatile organic molecules (other than acetate and formate). McCollom et al. (2015) indicated that around $60 \%$ of DOC in vent fluids from a ultramafic hosted hydrothermal system could be explained by organic acids and a small fraction by total hydrolysable amino acids (3-5\%, based on Lang et al., 2013). Therefore, an important fraction of DOC is currently unaccounted for. Other studies have reported a loss of organic acids during short periods of time during sample storage at $4{ }^{\circ} \mathrm{C}$ (Lang et al., 2010). These authors suggest that variability in the concentrations of volatiles, including complete absence, in hydrothermal fluids may be due to their rapid loss from samples, suggesting that many measurements of volatiles and DOC may underestimate true vent fluid concentrations.

Amino acids, sulfur compounds, and short- and long-chain hydrocarbons may also be present in hydrothermal fluids arising from biogenic, thermogenic or abiogenic processes (Shock, 1992; Simoneit, 2004; McCollom and Seewald, 2007; Klevenz et al., 2010; Lang et al., 2010, 2013; Reeves et al., 2014), and could contribute to the non-extractable DOC pool. With respect to hydrocarbons, Menez Gwen hydrothermal fluids have anomalously high methane and long-chain hydrocarbon concentrations compared to other basalt-hosted hydrothermal systems (Charlou et al., 2000; McCollom and Seewald, 2007 and references therein), indicating that this could be an important source of carbon. This is consistent with a metagenomic study of the microbial communities present in fluids collected outside of the fissure of the Woody vent, which indicate that the predominant genes are associated with short-chain hydrocarbon 
degraders (Meier personal communication), compounds that could also contribute to the non-extractable DOC pool.

\subsection{Changes of bulk parameters during the incubation experiment}

DOC and TDN concentrations decreased to $32 \%$ and $44 \%$ of their initial concentration over the first $12.5 \mathrm{~h}$ of the incubation, respectively (Table 1), suggesting that most of the vent fluid DOM was quickly decomposed during the incubation experiment. At the end of the experiment, DOC concentration was around $7 \%$ of the initial value, whereas TDN decreased to $31 \%$ of the initial concentration in the first $38 \mathrm{~h}\left(\mathrm{~T}_{2}\right)$ and remained low and stable within the analytical error thereafter. A sharp decrease in DOC, of $70 \%$ of its initial concentration (from ca. $300 \mu \mathrm{M}$ to $90 \mu \mathrm{M}$ ) in less than $20 \mathrm{~h}$, was reported by Lang et al. (2006) for fluids at the Baby Bare site. This decrease in DOC was also accompanied by a decrease in cell abundance and it was related to sedimentary influence in the fluids, because after $48 \mathrm{~h}$, the fluids became visibly clearer (Lang et al., 2006). Menez Gwen is an unsedimented hydrothermal system and thus this sedimentary effect may not be the cause of the DOC decrease observed in the first $12 \mathrm{~h}$ of our study. Potential presence of particles cannot be completely excluded due to the characteristics of the Woody crack site (see Section 2.1), but the lack of visual precipitation indicates bio-mineralization rather than loss associated with precipitation.

Contrary to DOC, TDN comprises both organic and inorganic forms of nitrogen and is not removed from the system via mineralization. Denitrification and other pathways that would form volatile forms of nitrogen are very unlikely to occur in our oxic experiment, thus the loss of TDN is presumed to be due to assimilation into biomass i.e., transformation into particulate organic matter. As a rough approximation, the observed $9 \mu \mathrm{M}$ decrease of TDN (Table 1 ) translates into little more than $50 \mu \mathrm{M}$ particulate organic carbon assimilated biomass (assuming Redfield stoichiometry). This is small compared to the measured $1.1 \mathrm{mM}$ of DOC removed from the system. This results in a bacterial growth efficiency, i.e. the carbon conversion factor into biomass, of only about $5 \%$. Such low growth efficiency is not untypical for marine environments with a high level of stress, such as strong temperature gradients or lack of suitable nutrients, or combination of various stressors (e.g. Carlson et al., 2007).

Winkel et al. (2014) performed a ${ }^{13} \mathrm{C}$-acetate assimilation experiment with diffusive fluids collected at the same Woody crack. They observed a rapid growth of heterotrophic microbes after adding $10 \mu \mathrm{M}$ of acetate in an $8 \mathrm{~h}$ aerobic incubation experiment, clearly confirming rapid incorporation of low molecular weight organic compounds by microbes present in these fluids. During this oxic incubation, addition of acetate favored a new microbial community which incorporated ${ }^{13} \mathrm{C}$ acetate and increased in cell abundance from $1.3 \times 10^{3}$ to $3.8 \times 10^{5}$ cell mL $^{-1}$ in $8 \mathrm{~h}$, thus increased 290 times its initial abundance (Winkel et al., 2014). Assuming the same growth rate for the initial microbial community $\left(1.6 \times 10^{5}\right.$ cell $\left.\mathrm{mL}^{-1}\right)$ reported by Winkel et al. (2014) but for $12 \mathrm{~h}$ for our incubation, 435 times increase in cell abundance in our experiment could be expected, this would represent $6.7 \times 10^{7}$ cell $\mathrm{mL}^{-1}$. Winkel et al. (2014) reported ${ }^{13} \mathrm{C}$ incorporation of 0.8 and $1.7 \mathrm{fmol}$ per cell for a lower and maximum detected consumptions of acetate, thus the microbial community may have the potential to assimilate 84 and $178 \mu \mathrm{mol}$ of carbon from the $1.5 \mathrm{~L}$ of fluids after $12 \mathrm{~h}$. Under consideration of our rough estimates of bacterial growth efficiency this would translate into a consumption of up to 1.7-3.6 $\mathrm{mM}$ DOC in the course of $12 \mathrm{~h}$. This estimate is only a rough approximation because it extrapolates the experimental findings from Winkel et al. (2014) to natural conditions, but it illustrates that the microbial heterotrophic community at the studied diffusive vent site is indeed capable to decompose the observed $1.1 \mathrm{mM}$ DOC in a very short time span of few hours.

A small increase in CDOM at the start of the experiment $\left(a_{254}\right.$; Table 1), indicated that microbes utilized the bio-available, non-colored DOC at the start of the experiment and produced aromatic material early in the experiment (Table 1 ). With further bio-degradation, $a_{254}$ decreased, indicating that CDOM originally in the vent fluid or produced microbially during the start of the incubation was bio-labile over this longer timeframe. Furthermore, SUVA 254 increased during the experiment, indicating that the surviving DOM pool was relatively enriched in aromatic carbon compared to the initial DOM (Stubbins et al., 2008) (Table 1, Fig. 3). The CDOM spectral slope, $\mathrm{S}_{275-295}$, became steeper during the course of the incubation, suggesting a decrease in the molecular mass of CDOM (Helms et al., 2008) (Table 1, Fig. 3). These results suggest that the remaining DOC pool was enriched in aromatic molecules that were already present in the hydrothermal fluid or were produced by the microbial utilization of labile DOM. However, future research is required to determine if this is the case for similar sedimented systems. The SPE-DOC showed limited biolability at this bulk level. Analyzing these SPE-DOC fractions via FT-ICR-MS unveiled a suite of molecular changes not apparent at the bulk level. These changes are detailed below.

\subsection{Molecular changes of SPE-DOM during the incubation experiment}

We identified 3018 molecular formulae via FT-ICR-MS in Woody vent fluid SPE-DOM of which $75 \%$ were related to the molecular groups of highly unsaturated, $14 \%$ polyphenols, $8 \%$ unsaturated aliphatics, $2 \%$ peptides and $1 \%$ were DBC (Table 2, Fig. $4 a$ ). More details are summarized in Table 2.

During the incubation 83\% of molecular formulae were conserved. These formulae may have represented resistant molecules from hydrothermal vent systems or the signature of highly refractory, deep ocean DOM. The latter likely contributed significantly to vent fluid molecular formulae as this fluid was comprised of 99\% seawater based upon $\mathrm{Mg}^{2+}$ concentrations and SPE-DOC concentrations in the vent fluid sample $(29 \mu \mathrm{M})$ were similar to those for deep ocean SPEDOC in regions remote from vent systems (Hansman et al., 2015). Nevertheless, some of the identified molecular formulae exhibited a decrease in intensity during the incubation (17\% of the formulae present in $\mathrm{T}_{0}$, Table 3 and Fig. 4).

These labile components were grouped based upon their apparent half-lives. Group A ( $7.3 \%$ of $\mathrm{T}_{0}$ formulae) had a half-life between 6 and $7 \mathrm{~h}$. Group B ( $2 \%$ of $\mathrm{T}_{0}$ formulae) was characterized by a half-life between 18 and $21 \mathrm{~h}$. Group C (only $0.5 \%$ of $\mathrm{T}_{0}$ formulae, Table 3 ) had a half-life between 4 and 7 days. Group $\mathrm{D}\left(7.5 \%\right.$ of $\left.\mathrm{T}_{0}\right)$ was characterized by a half-life between 5 and 106 days. Part of the observed decay of molecular formulae may be attributed to analytical variability, which was evaluated by the multiple analysis of an in-laboratory reference sample (SPE-DOM from North Equatorial Pacific Intermediate Water) randomly spaced with the analysis of the current samples. Using this assessment, group $\mathrm{C}$ was below the analytical error (NEqPIW 0.7\%) and is not discussed further.

Nine percent of formulae were fully decomposed during the experiment (sum groups A and B). Combining these formulae with those partially decomposed (group D) indicates that $17 \%$ of the formulae present in the initial DOM were biodegraded (Table 3). Labile SPE-DOC fractions were enriched in highly unsaturated O-rich and unsaturated aliphatic O-rich compounds (Tables 2 and 3, Fig. 4c). Degradation of formulae associated with O-rich highly unsaturated and unsaturated aliphatics is also indicated by a decrease in $\mathrm{O} / \mathrm{C}_{\mathrm{wa}}$, especially in the first $38 \mathrm{~h}$ of the experiment (Table 2). This labile DOM was less aromatic and, based on its average molecular composition $\left(\mathrm{C}_{18.19} \mathrm{H}_{22.80} \mathrm{O}_{8.98} \mathrm{~N}_{0.17} \mathrm{~S}_{0.10} \mathrm{P}_{0.00}\right)$, also more enriched in $\mathrm{H}, \mathrm{O}$ and $\mathrm{S}$ than the initial DOM, suggesting a preferential decomposition of more aliphatic oxygen- and sulfur-rich compounds (Tables 2 and 3 ).

Produced formulae, defined as those formulae which increased in intensity over time relative to $\mathrm{T}_{0}$, were also evaluated, but constituted only 27 formulae ( 22 already present in $\mathrm{T}_{0}$ ) and did not display a clear pattern. Therefore, we do not discuss them further. 
Bray Curtis dissimilarity
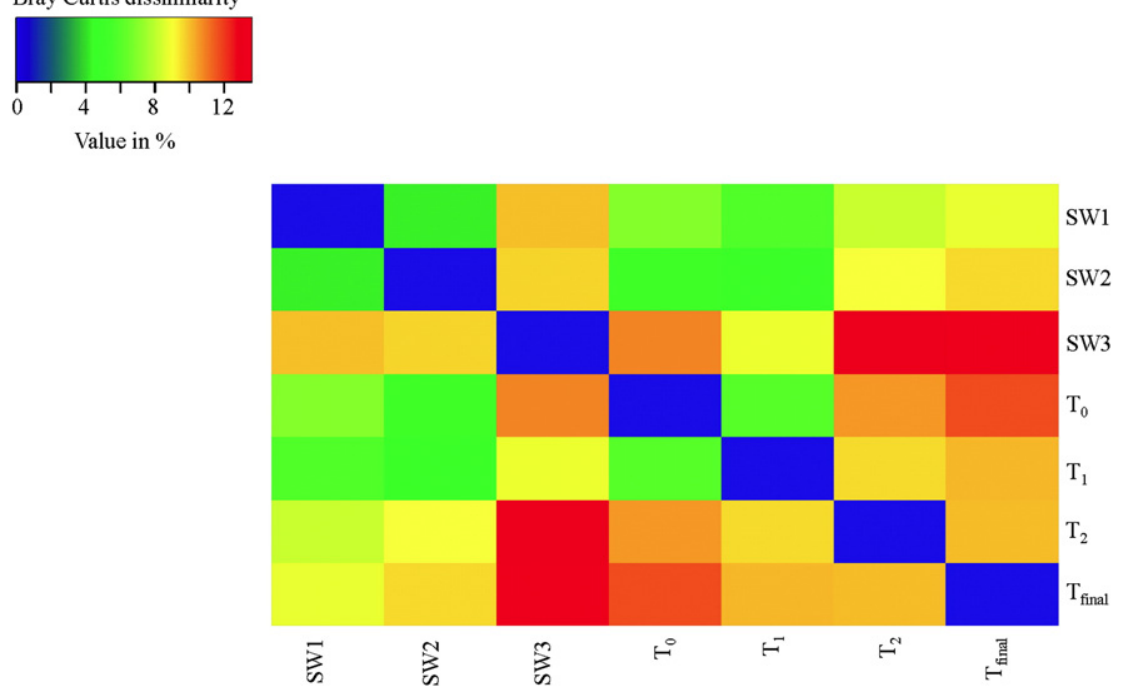

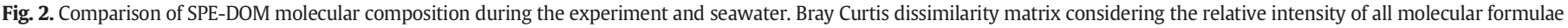
present in each sample.

Most molecular formulae (83\%) belonged to the group that did not show any consistent increase or decrease over time (group E). These apparently refractory molecular formulae closely follow the composition of $\mathrm{T}_{0}$ (Tables 2 and 3, Fig. 4c). Comparing the molecular characteristics of group $\mathrm{E}$ with the initial DOM, group $\mathrm{E}$ is more aromatic than the initial DOM, in agreement with the molecular characteristics of the $17 \%$ of formulae degraded during the incubation, which indicate preferential removal of non-aromatic compounds. Thus, despite the small fraction of the SPE-DOM decomposed in vent fluid, it was possible to assign bio-reactivities to individual molecular formulae (Fig. 4b and c). The decomposition of the aliphatic-rich, aromatic-depleted labile fraction of the SPE-DOM within vent fluids takes place on a scale of hours to years.

Based on FT-ICR-MS analysis, preferential decomposition of nonaromatic compounds (low AImod ${ }_{\text {wa }}$ ) leaves behind a DOM mixture enriched in aromatic molecules (high $\mathrm{AImod}_{\mathrm{wa}}$ ) and compounds of low molecular weight (low $\mathrm{MW}_{\mathrm{wa}}$ ) and lower $\mathrm{O} / \mathrm{C}_{\mathrm{wa}}$ at the end of the experiment, which is consistent with the observations from optical analysis during the experiment ( $\mathrm{SUVA}_{254}$ and $\mathrm{S}_{275-295}$, Fig. 3).

3.4. Molecular changes of SPE-DOM during the incubation experiment in relation to ambient, vent influenced SPE-DOM

DOM molecular formulae within the incubation were compared to molecular formulae for samples collected by CTD along a gradient of vent contributions as indicated by methane concentrations. Based on the range of dissimilarity according to the Bray Curtis analysis (color bar, Fig. 2), a small percentage of variation of up to $14 \%$ between the hydrothermal and CTD (SW1 to SW3) samples was observed. $\mathrm{T}_{0}$ and $\mathrm{T}_{1}$ were more similar to the seawater samples with the higher methane concentrations (SW1 and SW2, Table 1), while $\mathrm{T}_{2}$ and $\mathrm{T}_{\text {final }}$ were more dissimilar from $\mathrm{T}_{0}$ with approximately 11 and $12 \%$ dissimilarity, respectively. However, $\mathrm{T}_{2}$ and $\mathrm{T}_{\text {final }}$ were also $14 \%$ dissimilar from the seawater sample with the lowest methane concentration (SW3, Table 1).

In order to evaluate the compounds that make the SW3 different from the DOM in the experiment, the formulae that were present in $\mathrm{T}_{0}$ but not in SW3 were identified. These constituted 418 formulae, mainly associated to group A (161 formulae) and were represented by an intensityweighted average molecular formula of $\mathrm{C}_{17.18} \mathrm{H}_{21.89} \mathrm{O}_{8.10} \mathrm{~N}_{0.44} \mathrm{~S}_{0.71} \mathrm{P}_{0.01}$. These formulae likely derive from the hydrothermal fluids and are preferentially decomposed during the transport of the fluids in the water column. Furthermore, to assess if DOM added from seawater to the fluids may be decomposed, we identified those molecular formulae that were degraded during the experiment and which were in higher relative abundance in SW3 compared to the end of the experiment. A total of 259 formulae, which represented 9\% of those present in SW3, had these characteristics. These formulae were associated with groups A ( $2 \%$ of SW3); B (2\%) and D (5\%) of the experiment, with groups B and D above the analytical error. This suggests that under these conditions, a small

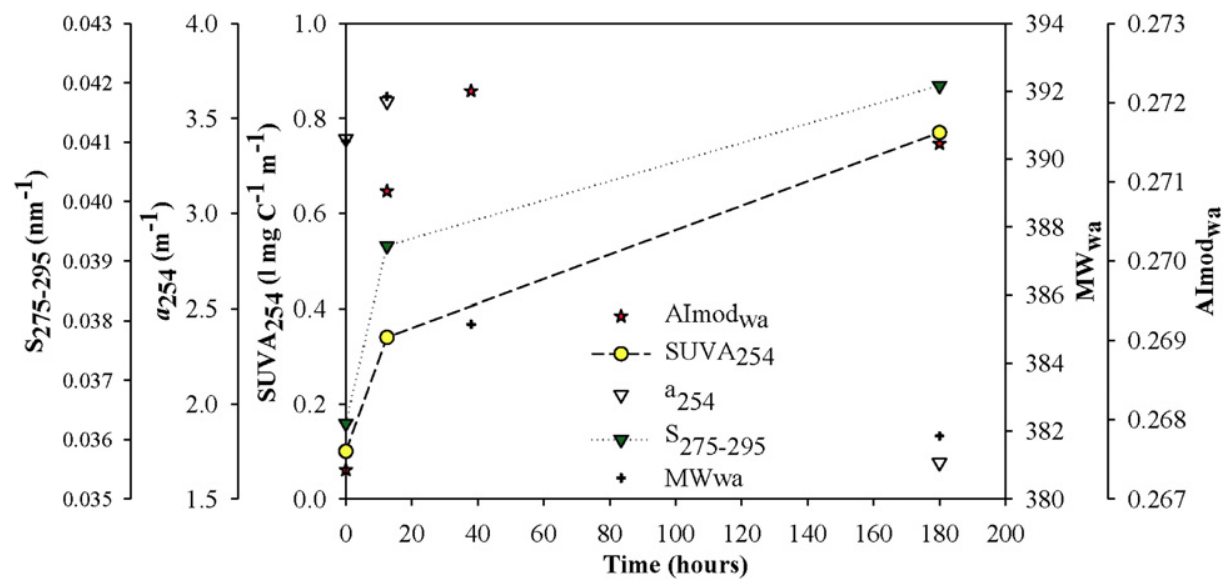

Fig. 3. Incubation of hydrothermal fluids, bulk parameters. $\mathrm{a}_{254}, \mathrm{SUVA}_{254}$ and $\mathrm{S}_{275-295}$ and $\mathrm{MW}_{\mathrm{wa}}$ and AImod wa , the latter two calculated from the molecular analysis of SPE-DOM. 
$\mathbf{a}$

b

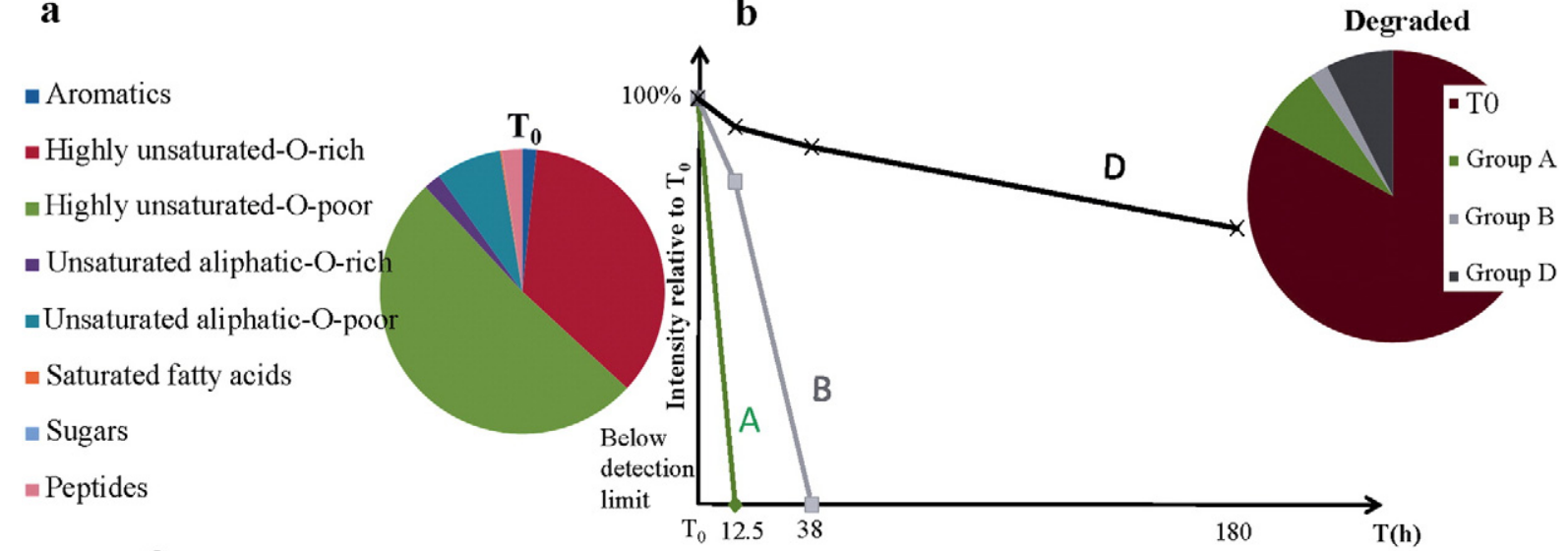

C

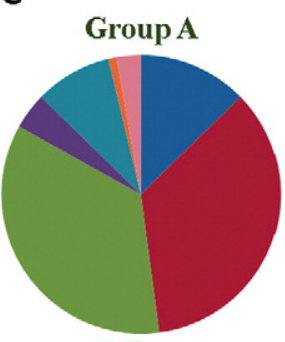

6-7h

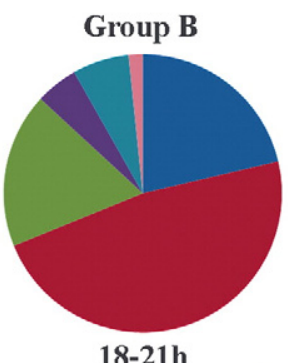

18-21h

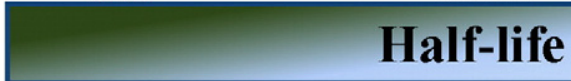

1-11 days

Group C
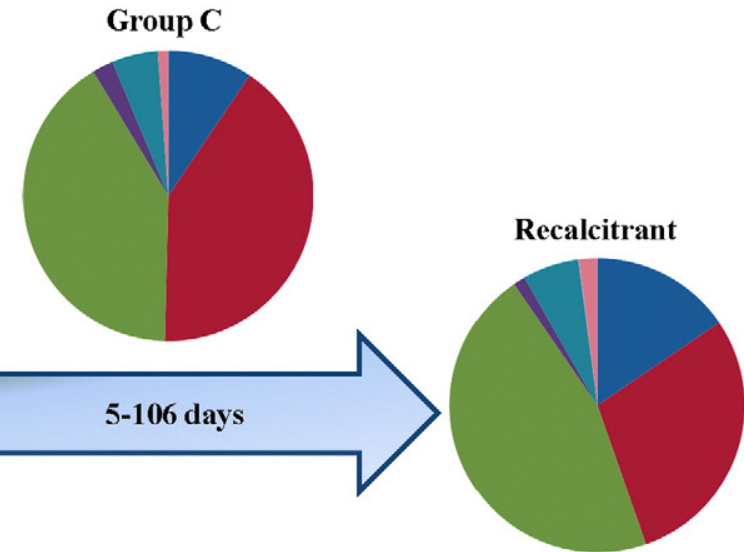

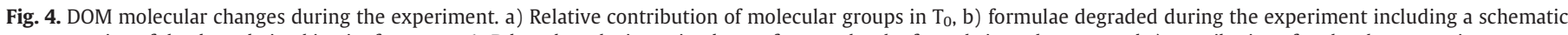

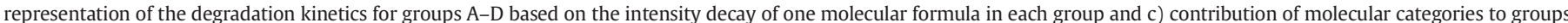

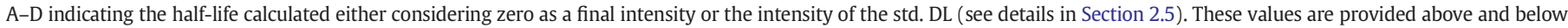
the half-life arrow, respectively.

fraction ( $7 \%$ from the sum of B and D) of the SPE-DOM from CTD samples was also altered on a molecular level, presumably due to microbial decomposition.

In seawater, $\mathrm{O} / \mathrm{C}_{\mathrm{wa}}$ and $\mathrm{DBE}_{\mathrm{wa}}$ decreased, and $\mathrm{AImod}_{\mathrm{wa}}$ increased with increasing methane concentrations. In the experiment the same trends were observed due to biodegradation (Table 2). This trends in $\mathrm{O} / \mathrm{C}$, DBE and AImod indicate that bio-labile DOM added from the vent fluids to the seawater is rich in oxygen and poor in aromatics and is preferentially decomposed during the experiment and also during the transport of the fluids away from the vents. Comparing the elemental composition of the intensity-weighted average molecular formulae, a decrease in $\mathrm{C}, \mathrm{H}$ and $\mathrm{O}$ and an increase in $\mathrm{N}$ with increasing methane concentrations in seawater were observed. In the experiment, a decrease after $12.5 \mathrm{~h}$ in $\mathrm{C}, \mathrm{H}$, and $\mathrm{O}$ was also observed while $\mathrm{N}$ behaved differently than in seawater, also decreasing during the incubation.
Among the N containing formulae, CHONS decreased in seawater with increasing methane concentration and also in the first $38 \mathrm{~h}$ of the experiment, in agreement with the $\mathrm{N}$ and $\mathrm{S}$ contributions in the intensity-weighted average molecular formula of those formulae present in $\mathrm{T}_{0}$ but not in SW3. On the contrary, contribution of CHON compounds increased with increasing methane concentration in seawater, and also as time progressed in the experiment, suggesting that some these compounds in the fluids were recalcitrant and got enriched in the remaining DOM during the experiment.

\subsection{Conclusions}

Incubation of DOM from a diffusive hydrothermal system revealed that non-extractable DOC was highly bioavailable, whereas bulk SPE-DOC was recalcitrant within analytical error (Table 1). Assessment

Table 3

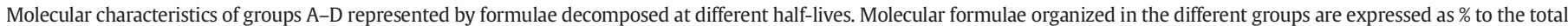
formulae in each degraded group.

\begin{tabular}{|c|c|c|c|c|c|c|c|c|c|c|c|c|c|c|c|c|}
\hline \multirow[t]{2}{*}{ Samples } & \multirow[t]{2}{*}{ \# of formulae } & \multirow[t]{2}{*}{$\%$ relative to $T_{0}$} & \multirow[t]{2}{*}{$\mathrm{H} / \mathrm{C}_{\text {wa }}$} & \multirow[t]{2}{*}{$\mathrm{O} / \mathrm{C}_{\mathrm{wa}}$} & \multirow[t]{2}{*}{ Almod $_{\text {wa }}$} & \multirow[t]{2}{*}{$\mathrm{DBE}_{\mathrm{wa}}$} & \multicolumn{2}{|c|}{$\begin{array}{l}\text { High.Uns. } \\
\text { O- }^{\mathrm{a}}\end{array}$} & \multicolumn{3}{|l|}{$\mathrm{DBC}-{ }^{\mathrm{a}}$} & \multicolumn{2}{|c|}{ Poly-O- ${ }^{a}$} & \multicolumn{2}{|c|}{$\begin{array}{l}\text { Uns. } \\
\text { Aliph.O- }{ }^{\text {a }}\end{array}$} & \multirow[t]{2}{*}{ Peptides } \\
\hline & & & & & & & Rich & Poor & $<\mathrm{C} 15$ & $\geq \mathrm{C} 15$ & CHOx & Rich & Poor & Rich & Poor & \\
\hline Group A & 221 & 7.3 & 1.30 & 0.48 & 0.19 & 8.07 & 4.1 & 8.6 & 0.5 & 0.5 & 0.5 & 0.9 & 1.0 & 37.6 & 33.9 & 2.7 \\
\hline Group B & 61 & 2.0 & 1.21 & 0.51 & 0.24 & 9.31 & 4.9 & 6.6 & 0.0 & 0.0 & 1.6 & 1.6 & 18.0 & 47.5 & 18.0 & 1.6 \\
\hline Group D & 225 & 7.5 & 1.25 & 0.50 & 0.24 & 7.81 & 2.7 & 5.8 & 0.0 & 0.0 & 0.4 & 0.9 & 9.3 & 33.3 & 46.2 & 1.3 \\
\hline Group E & 298 & 83 & 1.24 & 0.47 & 0.28 & 8.32 & 1.3 & 6.2 & 0.1 & 0.1 & 0.7 & 1.0 & 13.6 & 29.2 & 45.8 & 2.0 \\
\hline$A+B+C+D$ & 523 & 17 & 1.26 & 0.50 & 0.24 & 7.87 & 4.0 & 8.7 & 0.3 & 0.8 & 0.7 & 1.0 & 11.7 & 39.3 & 30.5 & 2.4 \\
\hline
\end{tabular}

\footnotetext{
a High.Uns. O-, DBC-, Poly-O- and Uns. Aliph.O- stand for highly unsaturated oxygen- (rich and poor), dissolved black carbon and unsaturated aliphatic oxygen- (rich and poor), respectively.
} 
of SPE-DOM biolability at the molecular level revealed a small fraction of the SPE-DOM molecular formulae were bioavailable (17\% of the molecular formulae decreased during the incubation). These formulae were degraded at different rates. Based upon FT-ICR-MS and $\mathrm{CDOM}$, non-aromatic compounds were preferentially decomposed, leaving more aromatic compounds (higher AImod ${ }_{\text {wa }}, \mathrm{SUVA}_{254}$ ), lower molecular weight ( $\left.\mathrm{MW}_{\mathrm{wa}}, \mathrm{S}_{275-295}\right)$, and lower $\mathrm{O} / \mathrm{C}_{\mathrm{wa}}$ DOM behind.

During bio-incubation, DOM from diffusive hydrothermal systems became more dissimilar to local, vent-influenced seawater on a molecular level. Of the molecular formulae present in seawater with lower hydrothermal contribution and the Woody fluid sample, $7 \%$ were higher in abundance in seawater than at the end of the experiment suggesting that a small fraction of SPE-DOM from seawater may be partially degraded around the biological hotspots of hydrothermal vents. With respect to the material that was elevated in vent fluids, trends in molecular properties during the incubation matched those observed with diminishing hydrothermal vent inputs to waters in the vicinity of the vent system, suggesting that a pool of labile material derived from vent fluids is degraded during transit away from vent systems. These trends indicate that vent systems are sources of labile DOC to deep ocean waters, yet may also represent sites of refractory DOC decomposition.

\section{Acknowledgments}

We thank Andrea Koschinsky and Kajta Schmidt for providing $\mathrm{Mg}^{2+}$ concentrations for the CTD samples and hydrothermal fluids at the Woody vent. We also acknowledge Eoghan Reeves and Xavier Prieto for the methane concentrations of the CTD samples and Nicole Dubilier and crew of the research cruise M82/3 for providing the samples. We thank Verona Vandieken for support during the analysis of volatile organic compounds and Matthias Friebe and Katrin Klaproth for support with DOC and data analyses, respectively.

\section{References}

Bischoff, J.L., Dickson, F.W., 1975. Seawater-basalt interaction at $200{ }^{\circ} \mathrm{C}$ and 500 bars: implications for origin of sea-floor heavy-metal deposits and regulation of seawate chemistry. Earth Planet. Sci. Lett. 25, 385-397.

Brault, M., Simoneit, B.R.T., Marty, J.C., Saliot, A., 1988. Hydrocarbons in waters and particulate material from hydrothermal environments at the East Pacific Rise, $13^{\circ} \mathrm{N}$. Org. Geochem. 12, 209-219.

Carlson, C.A., Del Giorgio, P.A., Herndl, G.J., 2007. Microbes and the dissipation of energy and respiration: from cells to ecosystems. Oceanography 20, 89-100.

Charlou, J.L., Donval, J.P., Douville, E., Jean-Baptiste, P., Radford-Knoery, J., Fouquet, Y. Dapoigny, A., Stievenard, M., 2000. Compared geochemical signatures and the evolution of Menez Gwen $\left(37^{\circ} 50^{\prime} \mathrm{N}\right)$ and Lucky Strike $\left(37^{\circ} 17^{\prime} \mathrm{N}\right)$ hydrothermal fluids, south of the Azores Triple Junction on the Mid-Atlantic ridge. Chem. Geol. 171, 49-75.

Dittmar, T., Stubbins, A., 2014. Dissolved organic matter in aquatic systems. In: Birrer, B. Falkowski, P., Freeman, K. (Eds.), 2nd ed. Treatise of Geochemistry vol. 12. Elsevier, pp. 125-156.

Dittmar, T., Koch, B.P., Hertkorn, N., Kattner, G., 2008. A simple and efficient method for the solid-phase extraction of dissolved organic matter (SPE-DOM) from seawater. Limnol. Oceanogr. Methods 6, 230-235.

Elderfield, H., Schultz, A., 1996. Mid-ocean ridge hydrothermal fluxes and the chemica composition of the ocean. Annu. Rev. Earth Planet. Sci. 24, 191-224.

Grbe-schönberg, D., Koschinsky, A., Ratmeyer, V., Jähmlich, H., Westernströer, U., 2006. KIPS-a new multiport valve-based all-teflon fluid sampling system for ROVs. Geophys. Res. Abstr. 8, 07032.

German, C.R., Seyfried, W.E., 2014. Hydrothermal processes. In: Birrer, B., Falkowski, P., Freeman, K. (Eds.), 2nd ed. Treatise of Geochemistry vol. 8. Elsevier, pp. 191-233.

Graue, J., Kleindienst, S., Lueders, T., Cypionka, H., Engelen, B., 2012. Identifying fermenting bacteria in anoxic tidal-flat sediments by a combination of microcalorimetry and ribosome-based stable-isotope probing. FEMS Microbiol. Ecol. 81, 78-87.

Green, N.W., Perdue, E.M., Aiken, G.R., Butler, K.D., Chen, H., Dittmar, T., Niggemann, J., Stubbins, A., 2014. An intercomparison of three methods for the large-scale isolation of oceanic dissolved organic matter. Mar. Chem. 161, 14-19.

Haase, K.M., Petersen, S., Koschinsky, A., Seifert, R., Devey, C.W., Keir, R., Lackschewitz, K.S , Melchert, B., Perner, M., Schmale, O., Süling, J., Dubilier, N., Zielinski, F., Fretzdorff, S. Garbe-Schönberg, D., Westernströer, U., German, C.R., Schank, T.M., Yoerger, D., Giere, O., Kuever, J., Marbler, H., Mawick, J., Mertens, C., Stöber, U., Walter, M., OstertagHenning, C., Pulick, H., Peters, M., Strauss, H., Sander, S., Stecher, J., Warmuth, M., Weber, S., 2007. Young volcanism and related hydrothermal activity at $5^{\circ} \mathrm{S}$ on the slow-spreading southern Mid-Atlantic Ridge. Geochem. Geophys. Geosyst. 8. http://dx.doi.org/10.1029/2006GC001509.
Hansman, R.L., Dittmar, T., Herndl, G.J., 2015. Conservation of dissolved organic matter molecular composition during mixing of the deep water masses of the northeast Atlantic Ocean. Mar. Chem. http://dx.doi.org/10.1016/j.marchem.2015.06.001.

Hawkes, J.A., Rossel, P.E., Stubbins, A., Butterfield, D., Connelly, D.P., Achterberg, E.P., Koschinsky, A., Chavagnag, V., Leleu, T., Dittmar, T., 2015. Dissolved organic carbon cycling in deep-ocean hydrothermal systems. American Society of Limnology and Oceanography, Aquatic Science Meeting, Granada, Spain.

Hedges, J.I., Eglinton, G., Hatcher, P.G., Kirchman, D.L., Arnosti, C., Derenne, S., Evershed, R.P., Kögel-Knabner, I., de Leeuw, J.W., Littke, R., 2000. The molecularly-uncharacterized component of nonliving organic matter in natural environments. Org. Geochem. 31, 945-958.

Helms, J.R., Stubbins, A., Ritchie, J.D., Minor, E.C., Kieber, D.J., Mopper, K., 2008. Absorption spectral slopes and slope ratios as indicators of molecular weight, source, and photobleaching of chromophoric dissolved organic matter. Limnol. Oceanogr. 53, 955-969.

Hu, C., Muller-Karger, F.E., Zepp, R.G., 2002. Absorbance, absorption coefficient, and apparent quantum yield: a comment on common ambiguity in the use of these optical concepts. Limnol. Oceanogr. 47, 1261-1267.

Kim, S., Kramer, R.W., Hatcher, P.G., 2003. Graphical method for analysis of ultrahighresolution broadband mass spectra of natural organic matter, the van Krevelen diagram. Anal. Chem. 75, 5336-5344.

Klevenz, V., Sumoondur, A., Ostertag-Henning, C., Koschinsky, A., 2010. Concentrations and distributions of dissolved amino acids in fluids from Mid-Atlantic Ridge hydrothermal vents. Geochem. J. 44, 387-397.

Koch, B.P., Dittmar, T., 2006. From mass to structure: an aromaticity index for highresolution mass data of natural organic matter. Rapid Commun. Mass Spectrom. 20, 926-932.

Koch, B.P., Witt, M., Engbrodt, R., Dittmar, T., Kattner, G., 2005. Molecular formulae of marine and terrigenous dissolved organic matter detected by electrospray ionization Fourier transform ion cyclotron resonance mass spectrometry. Geochim. Cosmochim. Acta 69, 3299-3308.

Kujawinski, E.B., 2002. Electrospray ionization Fourier transform ion cyclotron resonance mass spectrometry (ESI FT-ICR MS): characterization of complex environmental mixtures. Environ. Forensics 3, 207-217.

Lang, S.Q., Butterfield, D.A., Lilley, M.D., Johnson, H.P., Hedges, J.I., 2006. Dissolved organic carbon in ridge-axis and ridge-flank hydrothermal systems. Geochim. Cosmochim. Acta 70, 3830-3842.

Lang, S.Q., Butterfield, D.A., Schulte, M., Kelley, D.S., Lilley, M.D., 2010. Elevated concentrations of formate, acetate and dissolved organic carbon found at the Lost City hydrothermal field. Geochim. Cosmochim. Acta 74, 941-952.

Lang, S.Q., Früh-Green, G.L., Bernasconi, S.M., Butterfield, D.A., 2013. Sources of organic nitrogen at the serpentinite-hosted Lost City hydrothermal field. Geobiology 11, 154-169.

Lilley, M.D., Butterfield, D.A., Olson, E.J., Lupton, J.E., Macko, S.A., McDuff, R.E., 1993. Anomalous $\mathrm{CH}_{4}$ and $\mathrm{NH}_{4}^{+}$concentrations at an unsedimented mid-ocean-ridge hydrothermal system. Nature 364, 45-47.

Marcon, Y., Sahling, H., Borowski, C., dos Santos Ferreira, C., Thal, J., Bohrmann, G., 2013. Megafaunal distribution and assessment of total methane and sulfide consumption by mussel beds at Menez Gwen hydrothermal vent based on geo-referenced photomosaics. Deep-Sea Res. I 75, 93-109.

McCarthy, M., Beaupré, S.R., Walker, B.D., Voparil, I., Guilderson, T.P., Druffel, E.R.M., 2011. Chemosynthetic origin of ${ }^{14} \mathrm{C}$-depleted dissolved organic matter in a ridge-flank hydrothermal system. Nat. Geosci. 14, 32-36.

McCollom, T.M., 2008. Observational, experimental, and theoretical constraints on carbon cycling in mid-ocean ridge hydrothermal systems. In: Lowell, R.P., Seewald, J.S., Metaxas, A., Perfit, M.R. (Eds.), Magma to Microbe: Modeling Hydrothermal Processes at Ocean Spreading Centers. American Geophysical Union, pp. 193-213.

McCollom, T.M., Seewald, J.S., 2007. Abiotic synthesis of organic compounds in deep-sea hydrothermal environments. Chem. Rev. 107, 382-401.

McCollom, T.M., Seewald, J.S., German, C.R., 2015. Investigations of extractable organic compounds in deep-sea hydrothermal vent fluids along the Mid-Atlantic Ridge. Geochim. Cosmochim. Acta 156, 122-144.

McDermott, J.M., Seewald, J.S., German, C.R., Sylva, S.P., 2015. Pathways for abiotic organic synthesis at submarine hydrothermal fields. Proc. Natl. Acad. Sci. http://dx.doi.org/10. 1073/pnas.1506295112.

McLafferty, F.W., Turecek, F., 1993. Interpretation of Mass Spectra. University Science Books, Mill Valley, CA.

Mottl, M.J., Holland, H.D., 1978. Chemical exchange during hydrothermal alteration of basalt by seawater: I. Experimental results for major and minor components of seawater. Geochim. Cosmochim. Acta 42, 1103-1115.

Osterholz, H., Dittmar, T., Niggemann, J., 2014. Molecular evidence for rapid dissolved organic matter turnover in Arctic fjords. Mar. Chem. 160, 1-10.

Osterholz, H., Niggemann, J., Giebel, H.-A., Simon, M., Dittmar, T., 2015. Inefficient microbial production of refractory dissolved organic matter in the ocean. Nat. Commun. http://dx.doi.org/10.1038/ncomms8422.

Proskurowski, G., Lilley, M.D., Olson, E.J., 2008. Stable isotopic evidence in support of active microbial methane cycling in low-temperature diffuse flow vents at $9^{\circ} 50^{\prime} \mathrm{N}$ East Pacific Rise. Geochim. Cosmochim. Acta 72, 2005-2023.

Reeves, E.P., Prieto, X., Hentscher, M., Rosner, M., Seewald, J., Hinrichs, K.-U., Bach, W., 2011. Phase separation, degassing and anomalous methane at the Menez Gwen hydrothermal field. Mineral. Mag. 75, 1702

Reeves, E.P., McDermott, J.M., Seewald, J.S., 2014. The origin of methanethiol in midocean ridge hydrothermal fluids. Proc. Natl. Acad. Sci. 111, 5474-5479.

Riedel, T., Dittmar, T., 2014. A method detection limit for the analysis of natural organic matter via Fourier transform ion cyclotron resonance mass spectrometry. Anal. Chem. 86, 8376-8382. 
Roth, V.-N., Dittmar, T., Gaupp, R., Gleixner, G., 2013. Latitude and pH driven trends in the molecular composition of DOM across a north south transect along the Yenisei River. Geochim. Cosmochim. Acta 123, 93-105.

Schmidt, K., Koschinsky, A., Garbe-Schönberg, D., de Carvalho, L.M., Seifert, R., 2007. Geochemistry of hydrothermal fluids from the ultramafic-hosted Logatchev hydrothermal field, $15^{\circ} \mathrm{N}$ on the Mid-Atlantic Ridge: temporal and spatial investigation. Chem. Geol. 242, 1-21.

Schmidt, F., Elvert, M., Koch, B.P., Witt, M., Hinrichs, K.-U., 2009. Molecular characterization of dissolved organic matter in pore water of continental shelf sediments. Geochim. Cosmochim. Acta 73, 3337-3358.

Schultz, A., Delaney, J.R., McDuff, R.E., 1992. On the partitioning of heat flux between diffusive and point source seafloor venting. J. Geophys. Res. 97, 12299-12314.

Seidel, M., Beck, M., Riedel, T., Waska, H., Suryaputra, I.G.N.A., Schnetger, B., Niggemann, J., Simon, M., Dittmar, T., 2014. Biogeochemistry of dissolved organic matter in an anoxic intertidal creek bank. Geochim. Cosmochim. Acta 140, 418-434.

Shock, E.L., 1992. Hydrothermal organic synthesis experiments. Orig. Life Evol. Biosph. 22, $135-146$.

Simoneit, B.R.T., 2004. Prebiotic organic synthesis under hydrothermal conditions: an overview. Adv. Space Res. 33, 88-94.

Stubbins, A., Dittmar, T., 2012. Low volume quantification of dissolved organic carbon and dissolved nitrogen. Limnol. Oceanogr. Methods http://dx.doi.org/10.4319/lom. 2012.10.347.

Stubbins, A., Hubbard, V., Uher, G., Law, C.S., Upstill-Goddard, R.C., Aiken, G.R., Mopper, K., 2008. Relating carbon monoxide photoproduction to dissolved organic matter functionality. Environ. Sci. Technol. 42, 3271-3276.

Stubbins, A., Law, C.S., Uher, G., Upstill-Goddard, R.C., 2011. Carbon monoxide apparent quantum yields and photoproduction in the Tyne estuary. Biogeosciences 8, 703-713.
Summit, M., Baross, J.A., 2001. A novel microbial habitat in the mid-ocean ridge subseafloor. Proc. Natl. Acad. Sci. 98, 2158-2163.

Von Damm, K.L., Lilley, M.D., 2004. Diffuse flow hydrothermal fluids from $9.500 \mathrm{~N}$ Eas Pacific Rise: origin, evolution and biogeochemical controls. In: Wilcock, W.S.D. Delong, E.F., Kelley, D.S., Baross, J.A., Cary, C.S. (Eds.), The Subseafloor Biosphere at Mid-ocean Ridges. American Geophysical Union, Washington, DC, pp. 245-268.

Walker, B.D., McCarthy, M.D., Fisher, A.T., Guilderson, T.P., 2008. Dissolved inorganic carbon isotopic composition of low-temperature axial and ridge-flank hydrothermal fluids of the Juan de Fuca Ridge. Mar. Chem. 108, 123-136.

Wankel, S.D., Germanovich, L.N., Lilley, M.D., Genc, G., DiPerna, C.J., Bradley, A.S., Olson, E.J., Guirguis, P.R., 2011. Influence of subsurface biosphere on geochemical fluxes from diffusive hydrothermal fluids. Nat. Geosci. 4, 461-468.

Ward, N.D., Keil, R.G., Medeiros, P.M., Brito, D.C., Cunha, A.C., Dittmar, T., Yager, P.L., Krusche, A.V., Richey, J.E., 2013. Degradation of terrestrially derived macromolecules in the Amazon River. Nat. Geosci. http://dx.doi.org/10.1038/NGE01817.

Weishaar, J.L., Aiken, G.R., Bergamaschi, B.A., Fram, M.S., Fujii, R., Mopper, K., 2003. Evaluation of specific ultraviolet absorbance as an indicator of the chemical composition and reactivity of dissolved organic carbon. Environ. Sci. Technol. 37, 4702-4708.

Winkel, M., Pjevac, P., Kleiner, M., Littman, S., Meyerdierks, A., Rudolf, A., Mußmann, M. 2014. Identification and activity of acetate-assimilating bacteria in diffusive fluids venting from deep-sea hydrothermal systems. FEMS Microbiol. Ecol. 90, 731-746.

Yamanaka, T., Maeto, K., Akashi, H., Ishibashi, J.-I., Miyoshi, Y., Okamura, K., Noguchi, T., Kuwahara, Y., Toki, T., Tsunogai, U., Ura, T., Nakatani, T., Maki, T., Kubokawa, K., Chiba, H., 2013. Shallow submarine hydrothermal activity with significant contribution of magmatic water producing talc chimneys in the Wakamiko Crate of Kagoshima Bay, southern Kyushu, Japan. J. Volcanol. Geotherm. Res. 258, 74-84. 